students as a horst it is in fact not a horst but is an arch-like uplift with a few minor faults around it. Dr J. R. Vail (University of Khartoum) recorded that Sudan still provides many enigmas in the interpretation of basement structures, but that the Mozambique Belt can be traced from south to north, if perhaps in rather a zigzag fashion.

On the topic of mega-tectonics in Africa, flexibility of the African plate apparently gives the key to a new extra mechanism of global tectonics. Dr $\mathbf{H}$. Faure (Laboratoire de Géologie Dynamique, Bellevue, Paris) described undulations of the plate with wavelengths of the order of $100-1,000 \mathrm{~km}$, amplitudes (uplift) $10^{3}-10^{4} \mathrm{~m}$, over periods of 10-100 million years, each distinguished by individual histories of erosion and sedimentation. Professor B. C. King (Bedford College, London), on whom was conferred on April 21 the Murchison Medal for his work in Africa, forcefully demonstrated the marked difference between oceanic and continental rift systems. Dr M. J. Le Bas (University of Leicester) took the differences further and showed (see Nature, 230, 85; 1971) that many areas such as Kenya mark igneous provinces of characteristic per-alkaline magma (often including kimberlites) which are upswollen portions ("swells") of the African plate some $1,000 \mathrm{~km}$ across. It seems that the whole Earth has from time to time been deformed and rifted by these gigantic swells, caused by the degassing and/or volume expansion of parts of the Earth's interior. Professor R. A. Reyment (University of Uppsala) likewise demonstrated, from a very different angle, that the continental plate behaved in a most flexible manner, and he tilted and warped a plastic scale model of the African plate to simulate Earth movements and to reproduce known Cretaceous regressions and transgressions in West Africa. Professor A. J. Whiteman (University of Ibadan) also domes and rifts Nigeria and relates the rifting to the opening of the Atlantic Ocean.

M. H. Tazieff (Paris), who arrived half way through the colloquium hot from Etna, showed film taken a few days previously on Etna. $\mathrm{He}$ also described, again supported by the most magnificent filming, the ocean-rifting character of the northern Afar in Ethiopia, chiefly salt plains plus volcanoes, and pointed out the deplorable lack of geophysical stations in eastern Africa-a view echoed by Professor $\mathbf{R}$. M. Shackleton (University of Leeds) and Dr M. A. Khan (University of Leicester).

Looking to the future, Professor $\mathbf{R}$. M. Shackleton showed that more geophysical work should be undertaken, whether it be to discover more mineral deposits or to predict earthquakes and volcanicity or merely to understand better the processes of nature in Africa. Perhaps some results will be seen at the next colloquium to be held in 1973.

\section{NUCLEIC ACIDS \\ Isolating Messengers}

from our Cell Biology Correspondent

DETERMINING the sequence of an RNA molecule has become these daysthanks chiefly to the work of Sanger and his colleagues - so much a matter of routine that the chief problem is finding RNAs worth the effort of sequencing. Enough of the small RNAs of Escherichia coli and other organisms - the transfer RNAs, 5S
RNAs and the enigmatic bacterial $6 \mathrm{~S}$ RNA-have been sequenced to make the prospect of more of the same downright dull; the elucidation of sequence of $E$. coli ribosomal RNA is well on the way to completion and numerous groups are tackling one or other of the RNA phage RNAs. These molecules are of course the only messengers which can to date be obtained pure and in large quantities and it should not be long before the complete sequence of R17, for example, can be announced. Obviously the sequencers would love to get their hands on other messengers, particularly those of eukaryotic cells; that would restore excitement to their work and that is also why Blobel's work (Proc. US Nat. Acad. Sci., 68,

\title{
Changing Shape of Deception Island
}

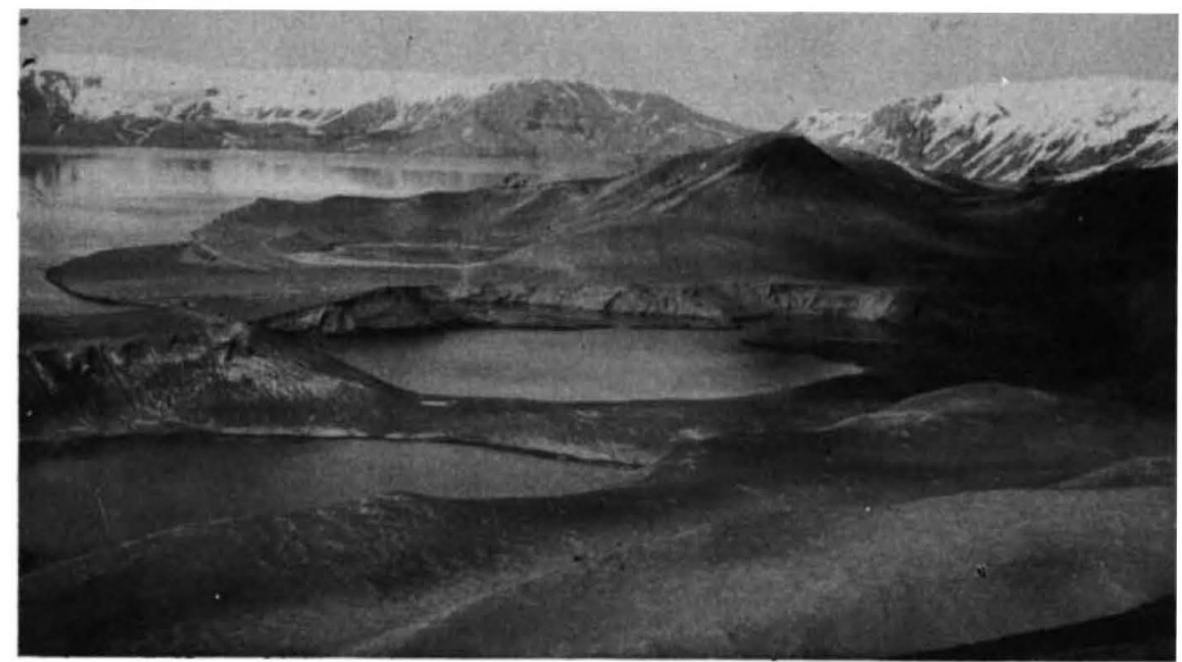

THE 1970 volcanic eruption on Deception Island in the Antarctic which partly destroyed a small island formed by a previous eruption and scattered ash and volcanic bombs over a substantial area, may have been a comparatively minor foretaste of what is to come. This is the conclusion of two geologists at the University of Leeds who, under the auspices of the Instituto Antártico Argentino, took part in an international survey of the changes to the island after the eruption on August 13. Their report, which is published in next Monday's Nature Physical Science, includes this photograph of some of the new volcanic centres.

Deception Is. is basically horseshoe shaped and encloses a large flooded caldera known as Port Foster. The earliest recorded eruption there seems to have taken place in 1842 , but apart from the probability of two further eruptions in 1910 and 1920 and some fumerolic activity the island seems to have been dormant until December 1967 when there began a series of events of which last year's eruption is the latest.

The 1967 eruption led to the forma- tion of a new island, the "1967 island" in Telefon Bay on the north-west side of Port Foster and there was an associated eruption farther to the east. Two years later there was a fissure eruption on the eastern side of the island and then last year there was more intense activity from an arcuate series of craters stretching from the south side of Cross Hill in the northwest of the island across Telefon Bay to the foot of Goddard Hill to the north-east. Among other things this activity led to the formation of a new strip of land across Telefon Bay, it partly destroyed the 1967 island and it enlarged the crater in the south-west of this former island. This crater now forms the largest of three interconnecting water filled craters, shown here, between the northern foot of Cross Hill and the remnant of the 1967 island.

All the eruptions in the past three years occurred on the inner side of the caldera and Baker and McReath believe them to be connected with movements and instability associated with the caldera fault. They say that further adjustments may take place anywhere in the caldera fault zone. 